\title{
Conspicuous work : peer working time, labour supply, and happiness for male workers
}

Citation for published version (APA):

Collewet, M. M. F., de Grip, A., \& de Koning, J. (2015). Conspicuous work : peer working time, labour supply, and happiness for male workers. Maastricht University, Graduate School of Business and Economics. GSBE Research Memoranda No. 012 https://doi.org/10.26481/umagsb.2015012

Document status and date:

Published: 01/01/2015

DOI:

10.26481/umagsb.2015012

Document Version:

Publisher's PDF, also known as Version of record

\section{Please check the document version of this publication:}

- A submitted manuscript is the version of the article upon submission and before peer-review. There can be important differences between the submitted version and the official published version of record.

People interested in the research are advised to contact the author for the final version of the publication, or visit the DOI to the publisher's website.

- The final author version and the galley proof are versions of the publication after peer review.

- The final published version features the final layout of the paper including the volume, issue and page numbers.

Link to publication

\footnotetext{
General rights rights.

- You may freely distribute the URL identifying the publication in the public portal. please follow below link for the End User Agreement:

www.umlib.nl/taverne-license

Take down policy

If you believe that this document breaches copyright please contact us at:

repository@maastrichtuniversity.nl

providing details and we will investigate your claim.
}

Copyright and moral rights for the publications made accessible in the public portal are retained by the authors and/or other copyright owners and it is a condition of accessing publications that users recognise and abide by the legal requirements associated with these

- Users may download and print one copy of any publication from the public portal for the purpose of private study or research.

- You may not further distribute the material or use it for any profit-making activity or commercial gain

If the publication is distributed under the terms of Article $25 \mathrm{fa}$ of the Dutch Copyright Act, indicated by the "Taverne" license above, 
Marion Collewet, Andries de Grip, Jaap de Koning

Conspicuous work: Peer working time, labour supply, and happiness for male workers

$\mathrm{RM} / 15 / 012$

\section{GSBE}

Maastricht University School of Business and Economics

Graduate School of Business and Economics

P.O Box 616

NL-6200 MD Maastricht

The Netherlands 


\title{
Conspicuous work:
}

\section{Peer working time, labour supply, and happiness

\author{
for male workers
}

Marion Collewet*, Andries de Gripł Jaap de Koning ${ }^{\ddagger}$

\begin{abstract}
This paper uncovers 'conspicuous work' as a new form of status seeking that can explain social interactions in labour supply. We analyse how peer working time relates to both labour supply and happiness for Dutch male workers. Using a unique measure of peer weekly working time, we find that men's working time increases with that of their peers and that peer working time is negatively related to men's happiness. These findings are consistent with a 'conspicuous work' model, in which individuals derive status from working time.
\end{abstract}

JEL Classification Numbers: J22, I31, D62.

Keywords: well-being; social norms; working hours

\footnotetext{
*Corresponding author: Marion Collewet, ROA and Department of Economics, Maastricht University, m.collewet@maastrichtuniversity.nl.

${ }^{\dagger}$ ROA and Department of Economics, Maastricht University; IZA; Netspar

¥SEOR, Erasmus University Rotterdam

$\S$ We thank Sarah Ayllon Gatnau, Jan Feld, Bert van Landeghem, Maarten Vendrik, and participants of the EALE conference (2011), DUHR seminar Maastricht (2013), Economics PhD seminar Maastricht (2013), IARIW conference (2014) and AIAS lunch seminar (2014) for their useful comments.
} 
Individuals' labour supply decisions appear to be influenced by their peers' behaviour. Different explanations have been developed for such mimetic behaviour, ranging from externalities generated by peer behaviour to status seeking on the part of the individual. This paper studies the role peer working time plays in an agent's utility function in order to find which motivations drive mimetic behaviour in labour supply at the intensive margin. To do so, we examine how peer working time relates to both the working time and happiness of individuals in a sample of Dutch men.

Several studies have found evidence of peer effects in working time (Woittiez and Kapteyn, 1998; Aronsson et al., 1999; Weinberg et al., 2004; Grodner and Kniesner, 2008). We add to this literature by using a unique measure of peer labour supply, namely, the average weekly working time of a man's acquaintances, as reported by the respondent himself. ${ }^{1}$

We want to shed light on the drivers of these peer effects in working time. We study the role of peer working time in an individual's utility function by examining the relation between peer working time and individual happiness. This means that we use self-reported happiness as a proxy for utility. This approach has yielded interesting insights for the study of the potentially imitative character of obesity (Blanchflower et al., 2009; Oswald and Powdthavee, 2007). We apply it to the study of working time.

In this paper, we first summarize the hypotheses given in the literature about the ways in which peer behaviour and peer working time in particular can enter an individual utility function. We identify three main models. First, peer working time can generate externalities and therefore influence the marginal utility of leisure or of work for an individual (e.g. see the spillover effects of Grodner and Kniesner, 2006). Second, an individual can have a preference for conformity and thus derive utility from working the same number of hours as his peers (see the conformity effects of Grodner and Kniesner, 2006). Third, the individual can derive status and therefore utility from the difference between his own working time and that of his peers (see the emulation model of Clark and Oswald, 1998). If the individual derives status from working less than his peers, this is a case of 'conspicuous leisure'. Alternatively, in what we call the 'conspicuous work' case, the individual derives status from working more than his peers, which increases his utility.

\footnotetext{
${ }^{1}$ Earlier studies use the working time of workers with characteristics similar to the individual's (e.g. Aronsson et al., 1999) or a working time variable constructed on the basis of other peer characteristics described by the individual (Woittiez and Kapteyn, 1998).
} 
Using data from the CentER data panel, a panel survey of Dutch households, for the period 1994-2011, we first find a positive relation between a man's working time and that of his peers, as found in earlier studies and as predicted by all three models mentioned above. Second, we find that men are less happy if their peers work more, even when controlling for their own working time and for their own and peer income. This is consistent with the conspicuous work model, in which individuals derive status from their working time and in which the optimal behaviour is to imitate one's peers because their utility function is concave in status. We use individual fixed effects to control for unobserved characteristics, including those that individuals might share with their peers, and additional robustness checks suggest that the relations identified here are not spurious.

The paper is structured as follows. The next section formulates different models, to be tested empirically, for the different ways in which peer labour supply can influence an individual's utility and his labour supply. It also gives a brief overview of the empirical literature. Section 3 describes the data. Section 4 tests the different models formulated earlier, first, by analysing the link between peer working time and men's own working time and, second, by studying how peer working time relates to men's happiness. Section 5 concludes the paper.

\section{Social Interactions in Labour Supply}

\subsection{Models of Social Interactions in Labour Supply}

\section{Externalities}

A first way to explain why individuals are affected by their peers' working time is to argue that peer working time generates externalities. Working alone or relaxing alone is arguably less enjoyable than working or relaxing with others. Alesina et al. (2006) present a simple model accounting for what they call a social multiplier effect in leisure and use it to explain differences in hours worked between the United States and Europe. Vendrik (1998) develops a model that explains long-run changes in labour supply by bandwagon effects, that is, by the fact that individual preferences are influenced by average behaviour in their social group. Grodner and Kniesner (2006) model a similar idea under the name spillover effects. Similarly, Stiglitz (2008) 
argues that the marginal utility of leisure decreases when others work more because it is more enjoyable to spend leisure time together. There is indeed evidence that individuals coordinate their working hours to have common leisure time within the household (Hamermesh, 2002) and within regions (Jenkins and Osberg, 2004).

The individual's utility function, in such a case, takes the form ${ }^{2}$

$$
U=U(h, h \bar{h}, c, X)
$$

where $h$ stands for the weekly working time of the individual, $\bar{h}$ is the weekly working time of the relevant peer group, $c$ is the consumption of market goods and services, and $X$ is a vector of personal characteristics and tastes. Here $U_{h \bar{h}}>0$, meaning that the individual enjoys working more the more his peers work.

In all the models presented in this section, the labour supply function takes the form

$$
H=H(w, y, \bar{h}, X)
$$

where $w$ represents the hourly wage rate an individual can command on the labour market and $y$ is his non-labour income. In the externalities model, $H_{\bar{h}}>0$, because an increase in peer hours leads to an increase in the marginal utility from work (and conversely to a decrease in the marginal utility from leisure) for the individual. ${ }^{3}$

\section{Conformity}

Second, peer working time can set a norm to which individuals want to conform. Akerlof's (1980) theory of social custom and the identity theory of Akerlof and Kranton (2000) state that an individual's utility will be enhanced through an increase in identity utility if he behaves as people from his social category are expected. In the case of working time, this means that an individual will dislike having working hours that deviate greatly from what is expected of people in his social category. His peers' working hours can be considered a reasonable proxy for what

\footnotetext{
${ }^{2}$ This is a specific form of an interaction model. We choose to test this form because it is common in the literature (Vendrik 1998; Grodner and Kniesner 2006).

${ }^{3}$ To allow for this interpretation, we need to abstract from the issue of the timing of work by assuming that everyone works roughly during the same hours.
} 
is expected. Vendrik (2003) develops a specific version of the theory of social custom for labour supply. Clark (2003) shows that unemployed men are happier if their peers are unemployed as well and interpret this as evidence that unemployment can constitute a social norm. Grodner and Kniesner (2006) call such normative effects of the average labour supply in a group conformity effects. Analogous to their model, we can model the individual utility function in this case as

$$
U=U\left((h-\bar{h})^{2}, h, c, X\right)
$$

where $U_{(h-\bar{h})^{2}}<0$, since there is a reputation cost of deviating from the social norm. This specification ensures that there is no reputation effect if the individual complies to the norm and a negative one if he deviates from it (see Clark 2003).

In the labour supply function, again, $H_{\bar{h}}>0$, because the longer a man's peers work, the more he is willing to work himself, since he wants to conform to the social norm of working long hours. ${ }^{4}$ Bernheim (1994) develops a model in which individuals who care about status derived from complying with the social norm tend to conform to a homogeneous standard of behaviour, even if their preferences regarding that behaviour differ. Social norms held by individuals or by the people around them have been shown to influence the division of household and market work in couples (Van der Lippe and Siegers, 1994). Stutzer and Lalive (2004) show that individuals in communities with a stronger social norm to work tend to have shorter unemployment durations. Burda et al. (2013) find that theories based on social norms are consistent with the distribution of work across genders in a number of countries.

\section{Status: Conspicuous leisure or conspicuous work?}

A third way to explain social interactions in labour supply is to start from the idea that individuals derive status from the difference between their own labour supply and that of others. Clark and Oswald (1998) develop a general model of the behavioural implications of striving for status through differentiation. Applying their model to the case in which status can be derived from labour supply behaviour, one obtains an individual utility function of the form

\footnotetext{
${ }^{4}$ Grodner and Kniesner (2006) show how conformity effects and spillover effects have different implications for peer effects on labour supply: While the former lead to labour supply tending towards the mean of the reference group, the latter lead to a snowball increase in labour supply.
} 


$$
U=U(s, h, c, X)
$$

where $s$ is a status term, which in our case can take the form $s=h-\bar{h}-$ in the case of what Clark and Oswald (1998) call additive comparisons - or $s=h / \bar{h}$ - in the case of ratio comparisons. How exactly this status term affects individual utility depends on whether individuals derive status from having more leisure than their peers or from working more.

Veblen (1899) coined the concept of conspicuous leisure, that is, the idea that individuals can prove their status not only by consuming expensive and exclusive goods (conspicuous consumption), but also by showing that they do not have to work much and can afford to learn all kinds of skills that are not directly productive. Frijters and Leigh (2008) depict individuals in present times as making trade-offs between investing in conspicuous consumption and in conspicuous leisure and show that the balance is shifting towards the first element as mobility increases and leisure activities are less easily registered by one's environment. In the presence of conspicuous leisure, we have $U_{s}<0$ and therefore also $U_{\bar{h}}>0$.

However, individuals nowadays also signal their status to others through working time itself. In many social groups, an individual can indeed increase his status by telling everyone that he is very busy, preferably even more than others around him. Symmetrically, he can lose status if he has less to do than others. We label the case in which working time is viewed as a provider of status conspicuous work. Clark and Oswald (1998, p. 144) cite emulation in labour supply as a possible application of their model: 'One example is the Japanese-style case of corporate cultures in which everyone works at high levels of effort. When performance gives status, either directly or through added earnings, the model predicts effort-following'. Experimental results by Falk and Ichino (2006) also seem in line with the idea of conspicuous work: They find that individuals are more productive in their job if they share a room with another worker than if they work alone. This is consistent with the hypothesis that the workers derive status from their relative productivity. This suggests that there is, by analogy, a possibility for individuals to derive status from their working time. Their results are also in line with an individual utility function that is concave in status: They find that sharing a room with another worker seems to increase productivity more for workers who are less productive. One can imagine that the 
increase in productivity is larger because the increase in status is also larger for those who lag further behind their peers in terms of productivity and therefore status. In the conspicuous work model, we have $U_{s}>0$ and therefore $U_{\bar{h}}<0$.

Clark and Oswald (1998) show that if individual utility functions are concave in social comparisons, those seeking status will tend to conform to the behaviour of others. This has the interesting implication that both conspicuous leisure and conspicuous work will lead to following behaviour in labour supply. In terms of the labour supply function presented above, we have $H_{\bar{h}}>0$ in the conspicuous leisure case, because if an individual's peers reduce their working time, the individual would need to reduce his as well to maintain his relative leisure position. Conversely, if his peers increase their working time, he can afford to increase his without losing status from conspicuous leisure while increasing the utility he derives from consumption through increased income from work.

In the case of conspicuous work, we also have $H_{\bar{h}}>0$ : If an individual's peers increase their working time, the individual will imitate them to maintain the status he derives from conspicuous work. The labour supply of his peers motivates a man to work more hours to improve his relative working time position. The working time of his peers influences his behaviour because of his preference for the status of a 'hard worker'.

To sum up, all three models of social interactions in labour supply predict a positive effect of peer working time on individual working time, but for different reasons, associated with different roles of peer working time in the individual utility function.

\subsection{Peer Effects in Working Time: Empirical Evidence and Link with Happiness}

\section{Empirical evidence of peer effects in working time}

There is evidence that individuals conform to the labour supply of those around them. Peer labour supply has been found to have an influence on mothers' labour market participation (Maurin and Moschion, 2009), exit rates from welfare programmes (Van der Klaauw and Van Ours, 2003), exit from unemployment (Topa, 2001), and effort provision of workers (Ichino and Maggi, 2000; Falk and Ichino, 2006). As far as the number of hours worked is concerned, various studies 
find evidence of peer effects. Woittiez and Kapteyn (1998) find that, for married women in the Netherlands, the desired number of hours worked is influenced by the working time of a peer group constructed on the basis of the characteristics of the women themselves and the characteristics of their peers as reported by these women. Aronsson et al. (1999) find that the number of hours worked by Swedish married men is influenced by the number of hours worked in a social reference group defined on the basis of age, educational level, and the presence of children in the household. Weinberg et al. (2004) find that the male employment rate in the neighbourhood influences the annual number of hours worked by young American men. Grodner and Kniesner (2008) construct a peer group based on a measure of economic proximity and find that this peer group's working time is positively related to the working time of married American men.

The estimation of peer effects raises, however, a number of methodological problems. First, most studies examining the effect of peer behaviour on labour supply have to make strong assumptions about the peer group. The studies about peer effects in working time mentioned above mainly construct peer groups based on demographic and/or geographic criteria. The only exception is the study of Woittiez and Kapteyn (1998), who construct their measure of peer working time using information provided by the respondents about whom they consider to be their peer group. Soetevent (2006, p. 222) regrets that this strategy 'was since then not copied by other researchers'. To our knowledge, subjective data about peer groups has still not been used in more recent years to estimate peer effects on labour supply.

A second problem is that one has to find a strategy to distinguish effects really caused by peer behaviour from what Manski (1993) calls correlated effects, that is, effects that are simply due to the fact that individuals and their peers share unobserved characteristics or that they are affected by the same environmental factors or shocks. Aronsson et al. (1999) use cohort fixed effects to account for changes in the preferences of the reference group as a whole, which enables them to control for time-invariant shared unobservables, but not for common shocks or shared unobservables that would vary over time. Grodner and Kniesner (2008) instrument the mean labour supply of a reference group using the mean labour supply in the adjacent reference group. For this technique to solve the problems mentioned, they have to assume that the labour supply in this adjacent reference group is not correlated with an individual's own labour supply, that is, no unobservables or common shocks are shared with this adjacent group and the mean 
labour supply of this adjacent group has no direct influence on men's own labour supply. Finally, Weinberg et al. (2004) use individual fixed effects and individual-specific experience profiles to correct for the influence of shared unobservables, both time invariant and time varying, but they cannot entirely rule out the effect of common shocks.

From the literature, we can conclude that there is evidence that a man's working time is influenced by the labour supply of his environment, even if not all methodological problems have been resolved yet. Understanding the potential mechanisms behind such peer effects could help us to better understand whether and how peer working time actually influences individual working time.

\section{Peer working time and happiness}

Peer influences, or social influences in general, are often mentioned in the literature as one of the possible drivers behind the link between working time and subjective well-being: 'Social custom and conditioning might affect subjective well-being and the gender division of labour' (Booth and Van Ours, 2008, p.F79)); 'Men might be more satisfied with longer working hours because the social norm is to work full-time' (Rätzel, 2009, p.21). Booth and Van Ours (2009) explain their finding that working full-time is positively associated with the life satisfaction of men and negatively associated with that of women due to the fact that couples behave according to traditional gender identities. However, to our knowledge, the way in which peer working time influences individual well-being has not yet been examined.

In this paper, we examine the link between peer working time and happiness to obtain a better picture of an individual's utility function. We are aware of the fact that self-reported happiness is only an imperfect proxy for utility, since individuals make mistakes in predicting their happiness when they make decisions (Kahneman and Thaler, 2006) and sometimes even seem to consciously choose something else than maximizing their happiness (Benjamin et al., 2012). Still, we believe that self-reported happiness and utility are sufficiently correlated for an analysis of happiness to yield interesting insights into characteristics of the utility function. Happiness data are used to study potential imitative behaviour by Oswald and Powdthavee (2007) and Blanchflower et al. (2009), who apply the model of Clark and Oswald (1998) to the case of obesity. They show that relative weight influences individual happiness and that this 
could lead to imitative obesity. We build on these contributions and test the model of Clark and Oswald (1998) along with two concurrent models in the case of relative labour supply.

\section{Data}

We use the CentER data panel, a panel survey held since 1993 among Dutch households. The estimation sample consists of men aged 23 to 60 (as in Booth and Van Ours, 2013) surveyed in the years 1994 to 2011. Table 1 presents descriptive statistics for the main variables in our estimation sample. We choose to focus on individuals with a positive weekly working time, unlike Booth \& Van Ours $(2008,2009,2013)$, because we want to determine the effects of weekly working time and would like to avoid picking up any effect of being employed rather than unemployed. To rule out any effect on happiness of being employed while one's peers are unemployed, we also exclude individuals who report zero as the average working time of their peers and those who indicate that most of their peers do not have a paid job. ${ }^{5}$

Table 1: Descriptive Statistics

\begin{tabular}{lcccc}
\hline Variable & Mean & Std. Dev. & Min & Max \\
\hline Happiness & 4.03 & 0.63 & 1 & 5 \\
Log net household income & 10.23 & 0.60 & 6.12 & 11.62 \\
Log net peer household income (11-point scale) & 1.99 & 0.23 & 0 & 2.40 \\
Weekly hours & 41.65 & 9.14 & 1 & 72 \\
Peer weekly hours & 39.63 & 5.49 & 1 & 70 \\
Looking for another job & 0.20 & 0.40 & 0 & 1 \\
Subjective health & 4.06 & 0.64 & 1 & 5 \\
Age & 43.96 & 9.08 & 23 & 60 \\
Number of children & 1.11 & 1.19 & 0 & 6 \\
Partner & 0.83 & 0.38 & 0 & 1 \\
\hline
\end{tabular}

The number of hours that respondents work is measured by a number of questions with respect to their normal (contractual) weekly working hours, their usual working hours, and any additional hours they work in a second job. To measure weekly working time, we add up the usual number of hours and hours worked in second jobs. The happiness of respondents was measured by their response to the question: 'All in all, to what extent do you consider yourself a happy person?', to which they could answer using a 5-point scale ranging from 'very happy' to

\footnotetext{
${ }^{5}$ In the robustness checks in Sections 4.1 and 4.2, we show that including non-working individuals and those with non-working peers does not substantially change the results.
} 
'very unhappy'. ${ }^{6}$ Figure A1 presents histograms of the distributions of the happiness and hours variables that are central to the analysis.

The questions about an individual's peers were introduced as follows: 'The following questions concern your circle of acquaintances, that is, the people with whom you associate frequently, such as friends, neighbours, acquaintances, or maybe people at work'. The labour supply of the people in the respondents' environment was measured using two separate questions for men and women, formulated as follows: 'If you think of the men among your acquaintances, how many hours per week do they work on average?'. Figure A2 shows how peer working time relates to an individual's own working time. The answers about peer working time are concentrated along horizontal lines, which seems to indicate that the respondents used the focal points constituted by a number of standard weekly work durations (e.g. 30, 36, 38, 40, 45, 50, and 60 hours). If individuals would use their own working time as a proxy for their peers' working time, most observations would be concentrated on the 45-degree line. We see that this is not the case, which is reassuring, because it means that reporting bias is unlikely to play a big role in our analysis.

The questionnaire also contained a number of questions about the age of most of the respondent's acquaintances (in five-year age groups), the number of persons in most of these acquaintances' household, the average total net income per year of those households (in 11 categories), the level of education of most of the acquaintances (in seven categories), and the kind of employment of most of the acquaintances. Table $\mathrm{C} 1$ and Table $\mathrm{C} 2$ compare the characteristics of men in our sample to those of their peers. The figures show that men in our sample are generally similar to their peers but that, as one could expect, not everyone classifies the majority of their peers as similar to themselves in terms of age, education level, household size, and so forth. This demonstrates that directly collecting information on peer characteristics has real added value.

We lose about a quarter of the observations on working men aged 23 to 60 due to non-response on the peer labour supply and happiness questions. Using the test designed by Wooldridge (1995), we find that this does not lead to selection bias in our estimates (results available from the authors). The response to the question about the average income of the respondent's acquaintances is lower (only about 50\%) than for other items relating to peers. To avoid losing too many obser-

\footnotetext{
${ }^{6}$ Those who answered that they 'don't know' were excluded from the sample. They represent less than $1 \%$ of the sample.
} 
vations, we predicted the missing values for peer income as the linear prediction resulting from estimation of an ordered logit model with measured peer income as the dependent variable and measured peer characteristics as the independent variables (see Appendix B for more information about the prediction of peer income and about the cleaning of the data).

\section{Estimations}

\subsection{Peer Working Time and Individuals' Own Working Time}

All three models of social interactions in labour supply discussed above predict that the relation between individuals' own and peer working time should be positive. Therefore, we start by estimating this relation.

\section{Estimation method}

We estimate a fixed effects model. This is useful not only to control for unobserved heterogeneity among individuals but also, more importantly, to take into account unobserved characteristics that individuals can share with their peers and which can account for part of a positive relation between their own and peer working time. The standard errors are clustered at the individual level.

We do not observe hourly wages directly. Computing the hourly wage on the basis of total earnings and hours worked would cause a bias in its coefficients, since hours worked is the dependent variable in our analysis. Therefore, we follow Weinberg et al. (2004) by estimating a reduced form of the labour supply equation that does not include hourly wage. ${ }^{7}$

\section{Estimation results}

Table 2 presents the estimation results.

We first estimate a baseline model that does not include peer working time (column 1). Peer working time is added to this baseline model in column 2. The coefficient on the working time of male peers is positive and significant. The working time of female peers, when included in the

\footnotetext{
${ }^{7}$ Including hourly wage and non-earned income as regressors in the model does not cause the coefficient on peer working time to change.
} 
Table 2: Weekly Hours Worked: OLS Model with Fixed-Effects

\begin{tabular}{lccc}
\hline & $(1)$ & $(2)$ & $(3)$ \\
\hline Male peers' weekly hours & & $0.0999^{* * *}$ & $0.0939^{* * *}$ \\
Log net peer household income & & $(0.0285)$ & $(0.0288)$ \\
& & & 0.5682 \\
Age & $0.8885^{* * *}$ & $0.8695^{* * *}$ & $(0.5811)$ \\
& $(0.2721)$ & $(0.2696)$ & $(0.2703)$ \\
Age 2 & $-0.0113^{* * *}$ & $-0.0110^{* * *}$ & $-0.0109^{* * *}$ \\
& $(0.0029)$ & $(0.0029)$ & $(0.0029)$ \\
Number of children & -0.1005 & -0.0977 & -0.0999 \\
& $(0.2670)$ & $(0.2592)$ & $(0.2601)$ \\
Partner & 0.4684 & 0.4310 & 0.3965 \\
& $(0.7843)$ & $(0.7826)$ & $(0.7815)$ \\
Constant & $25.0427^{* * *}$ & $21.1676^{* * *}$ & $20.8889^{* * *}$ \\
& $(6.1088)$ & $(6.3047)$ & $(6.3241)$ \\
\hline Observations & 8203 & 8203 & 8203 \\
Individuals & 3042 & 3042 & 3042 \\
$R^{2}$ & 0.02 & 0.03 & 0.03 \\
\hline Standard errors (clustered by individual) in & parentheses; & p $<0.1 ; * *$ \\
p $<0.05 ; * * *$ \\
p $<0.01 ;$ Year dummies included as additional controls.
\end{tabular}

model, is not significant (results available from the authors). In addition, including the hours worked by the individual's partner does not affect the coefficient on peer working time (results available from the authors). The coefficient on peer working time remains positive and even hardly changes when peer income is added to the model as a regressor (column 3 ). ${ }^{8}$

Our results are in line with evidence of peer effects on working time found in earlier studies. In their estimation of peer effects on labour supply, Woittiez and Kapteyn (1998) and Grodner and Kniesner (2008) include a lag of individuals' own working time to control for habit formation in the labour supply. Following their example (see column 1 of Table C3), we find that habit formation indeed plays a role, but that the coefficient on peer working time remains virtually unchanged. ${ }^{9}$

\footnotetext{
${ }^{8}$ The coefficient on peer income, however, is larger when peer hours are not included in the model.

${ }^{9}$ We are aware that including a lag of the dependent variable as a regressor in a fixed effects model leads to bias (Nickell 1981). In a pooled model, the coefficient on peer working time drops by half when lagged individual's own hours are included, but both variables remain significant at the $1 \%$ level.
} 
The positive coefficient on peer working time, which remains smaller than one, suggests that individuals tend to follow the labour supply of their peers, without engaging in an explosive rat race.

\section{Robustness checks}

We estimate a number of additional models to check for the role of various potential sources of bias in our estimation results. Table 3 presents an overview of the results of various robustness checks we conducted. The fixed effects baseline model reproduced in row 0 of the table is the point of reference.

Table 3: Overview of Robustness Checks for the Weekly Hours Estimations

\begin{tabular}{llll}
\hline & Potential source of bias & Estimation method & $\begin{array}{l}\text { Coefficient on } \\
\text { peer working } \\
\text { time }\end{array}$ \\
\hline 0 & & Fixed-effects model (baseline) & $0.0939^{* * *}$ \\
1 & $\begin{array}{l}\text { Reverse causality } \\
\text { (Endogenous effects) }\end{array}$ & Use lag of peer working time & $0.0611^{* *}$ \\
2 & $\begin{array}{l}\text { Influence of other peer } \\
\text { characteristics } \\
\text { (Exogenous effects) }\end{array}$ & $\begin{array}{l}\text { Control for other observed peer } \\
\text { characteristics }\end{array}$ & $0.0857^{* * *}$ \\
3 & $\begin{array}{l}\text { Time-invariant } \\
\text { unobservables (Correlated } \\
\text { effects 1) }\end{array}$ & $\begin{array}{l}\text { Pooled model for comparison } \\
\text { with fixed-effects model }\end{array}$ & $0.4158^{* * *}$ \\
4 & $\begin{array}{l}\text { Common shocks (e.g. in } \\
\text { labour demand) } \\
\text { (Correlated effects 2) }\end{array}$ & $\begin{array}{l}\text { Desired working time as } \\
\text { dependent variable }\end{array}$ & $0.0677^{*}$ \\
5 & Endogenous controls & $\begin{array}{l}\text { Drop potentially endogenous } \\
\text { controls }\end{array}$ & $0.1001^{* * *}$ \\
\hline
\end{tabular}

1. First, we want to examine the role of possible feedback effects from the individual's own working time to peer working time (endogenous effects in Manski's (1993) terminology). Therefore, we also estimate the model replacing the present value of peer working time by its 
one-year lagged value. The estimation results are presented in column 2 of Table C3. The coefficient on the lag of peer working time is still positive and significant. ${ }^{10}$

2. Second, to account for what Manski calls exogenous effects, we check whether observable characteristics of peers other than their working time have an influence on an individual's working time. We include the peer characteristics that are measured in our dataset as additional regressors in the model. The estimation results are presented in column 3 of Table C3. We find that most added peer characteristics have no significant influence on an individual's working time.Most importantly, controlling for additional peer characteristics does not affect the coefficient on peer working time much.

3. Third, we argued above that estimating a fixed effects model eliminates the role of timeinvariant characteristics that individuals might share with their peers and which might influence both their peers' and their own working time. To check this argument, we compare our estimates with those of a pooled model in Table C4. This table shows that the coefficient on peer working time is indeed four times larger in pooled estimations, which confirms that using fixed effects corrects for the role of confounding factors.

4. Then, a man's working time and that of his peers can both be determined by external factors, such as labour demand. We therefore estimate a model in which the dependent variable is no longer actual hours worked but, instead, the man's desired working time ${ }^{11}$ (Table C5), because the desired working time is less likely to be influenced by labour demand conditions than the actual working time. The estimation results show that peer working time still has a positive influence on desired working time. This suggests that the positive relation is not purely driven by demand factors.

5. Next, for the reader worried about the potential endogeneity of control variables such as peer income, having a partner, or the number of children, we also re-estimated our model leaving out these control variables. The main results were not affected (see Table 3; full results available from the authors).

\footnotetext{
${ }^{10}$ Individuals can change peers over time. We assume that the peer group does not change much from one year to another and, also, that the working time of peers does not change much. Further lags of peer working time were not significant.

${ }^{11}$ The question about desired hours is phrased as follows: 'How many hours per week WOULD YOU LIKE to work in total? If you have more than one job, give the sum total for all jobs'.
} 
Finally, the reader might be worried about selection bias, because we estimate a labour supply model using only working individuals with working peers. However, when we remove the restriction of the positive individual's own and peer working time on our sample, the sample size increases only to $\mathrm{n}=9261$, with 3346 individuals. This means that about $90 \%$ of individuals in our sample work and have peers who work. The chances of selection bias are therefore very limited.

To sum up, we have addressed the role of time-invariant characteristics shared with peers, labour demand conditions, reverse causality (feedback effects), and selection bias. ${ }^{12}$ All in all, we consider the results of these robustness checks to be evidence that peer working time has a positive influence on a man's own working time. This is consistent with any of the models presented above in which peer working time enters the agent's utility function. In the following section, we want to discriminate between these concurrent models by turning to the link between peer working time and happiness.

\subsection{Peer Working Time and Happiness}

\section{Estimation method}

In this section, we examine the relation between peer working time and the happiness of male workers. Earlier research has demonstrated that in studies of self-reported happiness, it is crucial to take individual fixed effects into account (e.g. Lykken and Tellegen, 1996). Moreover, individual fixed effects offer a partial solution to the problem of potential endogeneity of an individual's own and peer working time. If individuals share some time-invariant characteristics with their peers that influence both working time and happiness, not controlling for them could lead to bias in the coefficient of peer working time.

For simplicity, we estimate a linear model with fixed effects. Because our dependent variable is discrete, we also estimate ordered logits with individual fixed effects for comparison purposes. Using both the method of Ferrer-i Carbonell and Frijters (2004) (FCF) and the 'blow-up and

\footnotetext{
${ }^{12}$ To try and tackle any potential remaining issues, we also estimated a model in which we instrumented for peer working time using peer age as an instrument. The effect of peer working time became so imprecisely estimated that it could not be statistically distinguished from zero. Consequently, the Hausman test did not reject the null hypothesis of exogeneity of peer working time. Overall, the evidence yielded by instrumenting peer working time was inconclusive.
} 
cluster' (BUC) method of Baetschmann et al. $(2011),{ }^{13}$ we find, as Ferrer-i Carbonell and Frijters (2004), that the estimation results are not substantially different when using ordered logits with fixed effects (see Table C6).

\section{Estimation results}

Table 4 presents the estimation results.

First, in column 1, we estimate a model without peer working time, concentrating on men's own hours and net household income. To allow for possible non-linear effects of hours on happiness, the estimation includes a quadratic term for weekly hours.

In columns 2 to 5 , we test the three models of social interactions presented in Section 2 by examining how peer working time relates to individual happiness. Column 2 presents a test of the externalities hypothesis by including the interaction of a man's own working time with peer working time. If individuals enjoy working more when their peers work more hours, we expect a positive sign on the coefficient of the interaction term. This is not the case here, which seems to invalidate the externalities hypothesis. ${ }^{14}$

To test the conformity model, we include the square of the difference between a man's working time and the weekly hours of his peers (column 3). The coefficient of this variable is positive and significant, which is at odds with the idea that men conform to their peers' working time because of social norms or externalities in work or leisure.

In columns 4 and 5, we test the status model in its additive comparison and its ratio comparison versions, respectively. The sign on the status term enables us to determine whether individuals derive utility from conspicuous leisure or from conspicuous work. In column 4, we introduce male peer working time into the regression. Note that this is practically equivalent to introducing the difference between an individual's own and peer working time, since we already control for his own working time. Conspicuous leisure would imply a positive coefficient on peer working time, while the conspicuous work model would predict the opposite. Peer working time appears to be negatively associated with happiness, therefore supporting the latter model. This conspicuous work effect holds even if peer income is included in the model, so it does not only

\footnotetext{
${ }^{13}$ We are thankful to Andy Dickerson for providing us with his code (Hole et al., 2011).

${ }^{14}$ The interaction term is not significant either in a model including only a linear hours term.
} 
Table 4: Happiness: OLS Model with Fixed-Effects

\begin{tabular}{|c|c|c|c|c|c|}
\hline & $(1)$ & $(2)$ & $(3)$ & $(4)$ & $(5)$ \\
\hline Weekly hours & $\begin{array}{c}0.0093^{* *} \\
(0.0042)\end{array}$ & $\begin{array}{c}0.0174^{* *} \\
(0.0088)\end{array}$ & $\begin{array}{c}0.0197^{* * *} \\
(0.0063)\end{array}$ & $\begin{array}{c}0.0096^{* *} \\
(0.0042)\end{array}$ & $\begin{array}{c}0.0090^{* *} \\
(0.0042)\end{array}$ \\
\hline Weekly hours 2 & $\begin{array}{c}-0.0001^{*} \\
(0.0000)\end{array}$ & $\begin{array}{l}-0.0001 \\
(0.0000)\end{array}$ & $\begin{array}{c}-0.0002^{* * *} \\
(0.0001)\end{array}$ & $\begin{array}{c}-0.0001^{*} \\
(0.0000)\end{array}$ & $\begin{array}{c}-0.0001^{*} \\
(0.0000)\end{array}$ \\
\hline Own hours $*$ peer hours & & $\begin{array}{l}-0.0002 \\
(0.0002)\end{array}$ & & & \\
\hline$(\text { Own hours - peer hours })^{\wedge} 2$ & & & $\begin{array}{c}0.0002^{* *} \\
(0.0001)\end{array}$ & & \\
\hline Male peers' weekly hours & & $\begin{array}{c}0.0059 \\
(0.0092)\end{array}$ & & $\begin{array}{c}-0.0041^{* *} \\
(0.0020)\end{array}$ & \\
\hline Hours ratio & & & & & $\begin{array}{c}0.0145^{* * *} \\
(0.0046)\end{array}$ \\
\hline Log net household income & $\begin{array}{l}0.0251^{*} \\
(0.0148)\end{array}$ & $\begin{array}{l}0.0256^{*} \\
(0.0146)\end{array}$ & $\begin{array}{l}0.0255^{*} \\
(0.0148)\end{array}$ & $\begin{array}{l}0.0263^{*} \\
(0.0147)\end{array}$ & $\begin{array}{l}0.0246^{*} \\
(0.0148)\end{array}$ \\
\hline Log net peer household income & & $\begin{array}{l}-0.0387 \\
(0.0440)\end{array}$ & $\begin{array}{l}-0.0332 \\
(0.0447)\end{array}$ & $\begin{array}{l}-0.0438 \\
(0.0442)\end{array}$ & $\begin{array}{c}0.0041 \\
(0.0527)\end{array}$ \\
\hline Looking for another job & $\begin{array}{c}-0.0524^{* * *} \\
(0.0198)\end{array}$ & $\begin{array}{c}-0.0535^{* * *} \\
(0.0197)\end{array}$ & $\begin{array}{c}-0.0531^{* * *} \\
(0.0198)\end{array}$ & $\begin{array}{c}-0.0527^{* * *} \\
(0.0197)\end{array}$ & $\begin{array}{c}-0.0526 * * * \\
(0.0198)\end{array}$ \\
\hline Subjective health & $\begin{array}{c}0.0818^{* * *} \\
(0.0154)\end{array}$ & $\begin{array}{c}0.0825 * * * \\
(0.0154)\end{array}$ & $\begin{array}{c}0.0818^{* * *} \\
(0.0154)\end{array}$ & $\begin{array}{c}0.0824^{* * *} \\
(0.0154)\end{array}$ & $\begin{array}{c}0.0821^{* * *} \\
(0.0154)\end{array}$ \\
\hline Age & $\begin{array}{l}-0.0349^{*} \\
(0.0204)\end{array}$ & $\begin{array}{l}-0.0338^{*} \\
(0.0204)\end{array}$ & $\begin{array}{l}-0.0344^{*} \\
(0.0204)\end{array}$ & $\begin{array}{l}-0.0332 \\
(0.0204)\end{array}$ & $\begin{array}{l}-0.0353^{*} \\
(0.0204)\end{array}$ \\
\hline Age $^{-} 2$ & $\begin{array}{l}0.0004^{*} \\
(0.0002)\end{array}$ & $\begin{array}{l}0.0004^{*} \\
(0.0002)\end{array}$ & $\begin{array}{l}0.0004^{*} \\
(0.0002)\end{array}$ & $\begin{array}{l}0.0004^{*} \\
(0.0002)\end{array}$ & $\begin{array}{l}0.0004^{*} \\
(0.0002)\end{array}$ \\
\hline Number of children & $\begin{array}{l}-0.0039 \\
(0.0206)\end{array}$ & $\begin{array}{l}-0.0026 \\
(0.0205)\end{array}$ & $\begin{array}{l}-0.0029 \\
(0.0205)\end{array}$ & $\begin{array}{l}-0.0038 \\
(0.0207)\end{array}$ & $\begin{array}{l}-0.0040 \\
(0.0205)\end{array}$ \\
\hline Partner & $\begin{array}{c}0.3154^{* * *} \\
(0.0862)\end{array}$ & $\begin{array}{c}0.3194^{* * *} \\
(0.0863)\end{array}$ & $\begin{array}{c}0.3191^{* * *} \\
(0.0863)\end{array}$ & $\begin{array}{c}0.3194^{* * *} \\
(0.0863)\end{array}$ & $\begin{array}{c}0.3158^{* * *} \\
(0.0863)\end{array}$ \\
\hline Constant & $\begin{array}{c}3.6546^{* * *} \\
(0.4976)\end{array}$ & $\begin{array}{c}3.4848^{* * *} \\
(0.6324)\end{array}$ & $\begin{array}{c}3.4890^{* * *} \\
(0.5151)\end{array}$ & $\begin{array}{c}3.8357^{* * *} \\
(0.5099)\end{array}$ & $\begin{array}{c}3.6643^{* * *} \\
(0.5029)\end{array}$ \\
\hline Observations & 8,203 & 8,203 & 8,203 & 8,203 & 8,203 \\
\hline Individuals & 3,042 & 3,042 & 3,042 & 3,042 & 3,042 \\
\hline$R^{2}$ & 0.03 & 0.04 & 0.04 & 0.04 & 0.04 \\
\hline
\end{tabular}

Standard errors (clustered by individual) in parentheses; ${ }^{*} \mathrm{p}<0.1 ;{ }^{*} \mathrm{p}<0.05$; ${ }^{* * *} \mathrm{p}<0.01$; Year dummies included as additional controls. 
capture a relative income effect. ${ }^{15}$ In column 5 , we include the ratio of one's own weekly hours to peer weekly hours, to test the ratio comparison version of the model. We find a positive and significant relation between the hours ratio and happiness, again supporting the conspicuous work model.

Interestingly, only the working time of male peers is significantly associated with men's happiness. The working time of female peers is not significant when taken up in the regression (results available from the authors).

Since we have only a rather imprecise measure of peer income, we are not able to make hard conclusions about the relative influence of peer working time and peer income on happiness. A worker's own working time and peer working time could influence well-being because they are predictors of good career perspectives and therefore of lifetime income or because they are associated with consumption on the job (in the form of additional material benefits, e.g. a company car).

Clark and Oswald (1998) show that if utility is sufficiently concave in status, individuals will tend to follow the behaviour of their peers. The positive relation found between a man's own working time and the number of hours worked by his peers suggests that this should be the case here. To verify this, we estimate models in which status, as measured by the difference between a man's own hours and his peer's hours, is included non-linearly in the happiness regression (see Table C7). First, when taking up a quadratic status term (column 1), it seems individuals' utility is convex in status, since the sign of the quadratic term is positive. However, this positive sign seems to be driven by a limited number of extreme values in the difference between an individual's own hours and peer hours. ${ }^{16}$ Therefore, we also estimate the model while dropping individuals who said they worked more than twice as much as their peers, which corresponds to dropping 54 observations (column 2). In this case, the difference terms are no longer significant, but the sign of the quadratic difference in hours is negative. This latter result is in line with

\footnotetext{
${ }^{15}$ In fact, the coefficient on peer working time does not change much upon inclusion of peer income, while the coefficient for peer income loses its significance when peer working time is included. The correlation coefficient between peer working time and peer income is 0.24 .

${ }^{16}$ Including a cubic term of the status variable in the model or running a local polynomial regression of happiness on status shows that the utility function is concave over the range of hours differences in which most observations are concentrated, but convex for especially high values of these differences in hours (results available from the authors).
} 
the hypothesis of comparison-concave utility. Similar results are obtained when using the hours ratio rather than the difference in hours as a measure of status. ${ }^{17}$

More robust evidence in favour of comparison-concave utility is provided in column 3. Here, we create dummies for working fewer hours than peers, the same number of hours, or more hours. We classify an individual as working the same number of hours as his peers if the absolute value of the difference between his peers' working time and his own is two hours or less. The results indicate that working less than one's peers is negatively related to a man's happiness, while working more is not significantly related to happiness. In this model, the hours terms and status dummies are jointly significant at the $5 \%$ level $(\mathrm{p}<0.025)$. These results are robust to the exclusion of individuals who work more than twice as much as their peers (column 4). Altogether, this evidence explains why we find evidence of peer effects in our labour supply regressions, but only of very small magnitude.

\section{Robustness checks}

We conduct a number of robustness checks to rule out factors that may cause a spurious relation between peer working time and happiness and to eliminate other potential sources of bias. All robustness checks are carried out on the model for additive comparisons (column 4 in Table 4) because this is the simpler formulation of the conspicuous work model. Table 5 presents an overview of the robustness checks we conducted. For reference, the coefficient obtained in our baseline model is reproduced in row 0 of the table.

1. First, as in the case of labour supply, we want to control for the influence of peer characteristics other than working time and income. We therefore estimate a model controlling for the peer characteristics that are measured in our dataset. The estimation results are presented in Table C8. The coefficients on the additional controls are not significant and the coefficient

\footnotetext{
${ }^{17} \mathrm{~A}$ quadratic of the ratio of an individual's own hours to peer hours also has a positive and significant coefficient in the unrestricted estimation sample. In the restricted sample, it has a negative sign but is statistically insignificant. According to Clark and Oswald (1998), in a ratio comparisons model, there is following behaviour if $-u^{\prime \prime}(h / \bar{h})(h / \bar{h})-u^{\prime}(h / \bar{h})>0$, where $u$ is the contribution of status to utility. In the ratio comparisons model we estimated on the restricted sample, $u=0.26 *(h / \bar{h})-0.09 *(h / \bar{h})^{2}$, so that the values of the estimated coefficients support following behaviour for a ratio of individuals' own hours to peer hours above 0.72. Alternatively, if we estimate the model using the log of the hours ratio and a quadratic of this log, we also find a positive sign for the log and a negative sign for the quadratic, both statistically insignificant, if we restrict the estimation sample to those individuals with a ratio of their own hours to peer hours between 0.72 and 2 . They represent $95 \%$ of the original sample. All results are available from the authors.
} 
Table 5: Overview of Robustness Checks for the Happiness Estimations

\begin{tabular}{|c|c|c|c|}
\hline & Potential source of bias & Estimation method & $\begin{array}{l}\text { Coefficient on } \\
\text { peer working } \\
\text { time }\end{array}$ \\
\hline 0 & & Fixed-effects model (baseline) & $-0.0041^{* *}$ \\
\hline 1 & $\begin{array}{l}\text { Influence of other peer } \\
\text { characteristics } \\
\text { (Exogenous effects) }\end{array}$ & $\begin{array}{l}\text { Control for other observed peer } \\
\text { characteristics }\end{array}$ & $-0.0041^{* *}$ \\
\hline 2 & $\begin{array}{l}\text { Time-invariant } \\
\text { unobservables (Correlated } \\
\text { effects } 1 \text { ) }\end{array}$ & $\begin{array}{l}\text { Pooled model for comparison } \\
\text { with fixed-effects model }\end{array}$ & 0.0006 \\
\hline 3 & Endogenous controls & $\begin{array}{l}\text { Drop potentially endogenous } \\
\text { controls }\end{array}$ & $-0.0043^{* *}$ \\
\hline 4 & $\begin{array}{l}\text { Job change as potential } \\
\text { confounding factor }\end{array}$ & Control for tenure & $-0.0041^{* *}$ \\
\hline 5 & Selection bias & $\begin{array}{l}\text { Include non-working individuals } \\
\text { and those with non-working } \\
\text { peers for comparison purposes }\end{array}$ & $-0.0021^{*}$ \\
\hline
\end{tabular}


on peer working time does not change, which indicates that exogenous effects do not bias our estimation results.

2. Second, we argued above that the use of individual fixed effects eliminates potential time-invariant confounding factors. To check this argument, we also estimate a pooled version of our model (see Table C9). Peer working time turns out to be insignificant in the pooled model (column 2). This hints towards the presence of unobserved characteristics shared with peers that have a positive influence on both peer working time and individual happiness. If this is the case, the peer hours variable in the pooled model captures both the positive effect of these characteristics on happiness and the negative effect of peer hours due to conspicuous work, resulting in an insignificant coefficient. Indeed, in column 1 of Table C9, the effect of a man's own working time seems to be overestimated in the pooled model, since the quadratic hours term is insignificant and since taking the coefficients from the pooled model at face value suggests an optimal working time of 85 hours a week. This suggests the presence of unobserved characteristics that increase both the number of hours and happiness. In our main model, we correct for those characteristics by introducing individual fixed effects so that only the negative effect of peer working time on happiness due to conspicuous work is left to be captured by the model.

3. One might further be worried that other variables in the models estimated are endogenous (income, peer income, job satisfaction, health, partner, number of children) and that this endogeneity biases the coefficients on our variables of interest. However, when the model is estimated without these potentially endogenous control variables, the estimated coefficients on an individuals' own working time and peer working time remain similar (full results available from the authors).

4. Another potential source of concern is the idea that a job change could affect one's own working time, peer working time, and happiness at the same time, therefore driving a spurious relation between these variables. We do not directly observe job changes in our data, but we can construct a measure of job tenure. Including this measure as a control in our model or a dummy for recent job changers (with job tenure shorter than a year or shorter than two years) does not affect the coefficient on one's own working time and peer working time (full results available from the authors). 
5. For the reader worried that focusing on only working men with working peers might somehow distort the results, we also estimated our main models while including non-working men and men with non-working peers. The results remain qualitatively the same (full results available from the authors). ${ }^{18}$

In conclusion, the negative coefficient on peer working time that we found in our main model holds when we use different methods aiming at excluding different sources of spuriousness or bias. ${ }^{19}$ We conclude that the conspicuous work model is not invalidated. It has to be stressed, however, that both an individual's own working time and peer working time are measured by the respondents' answers to survey questions. Strictly speaking, we can therefore only say that men are happier if they have the feeling that they work more or that they do not work less than their male peers.

\section{Conclusions}

In this paper, we have correlated a unique measure of peer working time with both individual working time and individual happiness, to better understand how peer working time enters an individual's utility function. This enabled us to shed light on the drivers of social interactions in labour supply. We used the Dutch CentER panel and focused on men of working age. We used the respondents' answer to the question: 'If you think of the men among your acquaintances, how many hours per week do they work on average?'. A first descriptive look at the data confirms that the use of this unique measure of peer working time has added value compared with constructs based on individual characteristics, because individuals often report peer characteristics that differ from their own.

We presented three different models of the role peer working time can play in an individual's utility function. In the first model, individuals imitate their peers' labour supply because peer

\footnotetext{
${ }^{18}$ In addition, peer income has a negative and significant coefficient, which might be due to increased power since we gain about a thousand observations.

${ }^{19}$ A further potential source of endogeneity could be reverse causality. It would play a role if happier people are likely to choose different working hours and peer working hours. We attempted to tackle this problem by using instrumental variables for individuals' own and peer working hours. As instruments for one's own working time, we used the constraints on the respondents' labour supply, measured as the difference between the desired weekly working time reported by the respondents and their actual weekly working time. The instrument we used for peer working time was peer age, but the F-statistic for the first stage indicated that it was not a very strong instrument. Peer working time, when instrumented, remained negative and significant. The endogeneity test could not reject the exogeneity of the working time variables.
} 
working time generates externalities for them that directly affect the marginal utility they obtain from work or leisure. In the second model, people derive utility from conforming to their peers' labour supply behaviour because the latter constitutes a social norm. In the third model, individuals derive status from the difference between their peers' working time and their own. This third model can take two forms: In the conspicuous leisure model, individuals derive status from working less than others because this is interpreted as evidence of affluence. On the other hand, in the conspicuous work model, status is derived from working a great deal and therefore individuals derive utility from working more or not working less than their peers. All three models predict a positive effect of peer labour supply on one's own labour supply, but they differ with respect to their predictions about the effect of peer working time on happiness.

In line with all three models, we found evidence of peer effects on men's working time, in the sense that a man works more hours the longer his male peers work. This evidence is in line with the earlier results of Aronsson et al. (1999), Weinberg et al. (2004), and Grodner and Kniesner (2008). To distinguish between the three models, we studied the link between peer labour supply and happiness. We found that peer labour supply is negatively related to men's happiness, controlling for one's own working time, one's own income, and peer income. This finding is consistent with the conspicuous work model. The evidence suggests that the relations we find are robust to a number of potential sources of bias or spuriousness.

Our results are in line with a conspicuous work model with comparison-concave utility (i.e. decreasing marginal utility of status), convex costs of working time, and non-increasing marginal private utility of working time (Clark and Oswald, 1998). A preference for status derived from work induces men to follow their peers' labour supply but, because of the decreasing marginal utility of status and the increasing marginal net costs of working more, they do not engage in an explosive rat race. It is worth noting that our results do not necessarily imply an increasing trend in working time at the macro level. The fact that individuals tend to follow their peers can also explain a downward trend in weekly working time. ${ }^{20}$ In the conspicuous work model, a decrease in peer working time (e.g. due to an external shock) allows men to decrease their own working time without losing status.

\footnotetext{
${ }^{20}$ In fact, on average, usual weekly hours worked by men on their main job decreased in the Netherlands from 38.1 hours in 1994 to 35.7 hours in 2011 (Organisation for Economic Co-operation and Development (OECD), stats.oecd.org) and also decreased during the same period for most other OECD countries.
} 
These results shed light on the motivations behind following behaviour in terms of working time. A better understanding of such motivations can be important for the design of incentives. For instance, Aronsson and Johansson-Stenman (2013) examine the implications for taxation of taking into account not only the role played by relative consumption, but also the implications of conspicuous leisure, and conclude that while conspicuous consumption calls for progressive taxation, conspicuous leisure would justify regressive taxation in some cases and not affect optimal taxation in others. If individuals are motivated by conspicuous work rather than conspicuous leisure, the case for progressive taxation becomes stronger.

\section{References}

Akerlof, G.A. (1980). 'A theory of social custom, of which unemployment may be one consequence', The Quarterly Journal of Economics, vol. 94(4), pp. 749-775.

Akerlof, G.A. and Kranton, R.E. (2000). 'Economics and identity', The Quarterly Journal of Economics, vol. 115(3), pp. 715-753.

Alesina, A.F., Glaeser, E.L. and Sacerdote, B. (2006). 'Work and leisure in the u.s. and europe why so different', in (M. Gertler and K. Rogoff, eds.), NBER Macroeconomics Annual 2005, Volume 20, pp. 1-100, MIT Press.

Aronsson, T., Blomquist, S., Sacklén, H. et al. (1999). 'Identifying interdependent behaviour in an empirical model of labour supply', Journal of Applied Econometrics, vol. 14(6), pp. 607-626.

Aronsson, T. and Johansson-Stenman, O. (2013). 'Conspicuous leisure: Optimal income taxation when both relative consumption and relative leisure matter', The Scandinavian Journal of Economics, vol. 115(1), pp. 155-175.

Baetschmann, G., Staub, K.E. and Winkelmann, R. (2011). 'Consistent estimation of the fixed effects ordered logit model', IZA Discussion Paper nr.5443.

Benjamin, D.J., Kimball, M.S., Heffetz, O. and Rees-Jones, A. (2012). 'What do you think would make you happier? what do you think you would choose?', The American Economic Review, vol. 102(5), p. 2083. 
Bernheim, B.D. (1994). 'A theory of conformity', Journal of political Economy, vol. 102(5), pp. $841-877$.

Blanchflower, D.G., Landeghem, B. and Oswald, A.J. (2009). 'Imitative obesity and relative utility', Journal of the European Economic Association, vol. 7(2-3), pp. 528-538.

Booth, A.L. and Van Ours, J.C. (2008). 'Job satisfaction and family happiness: The part-time work puzzle', The Economic Journal, vol. 118(526), pp. F77-F99.

Booth, A.L. and Van Ours, J.C. (2009). 'Hours of work and gender identity: Does part-time work make the family happier?', Economica, vol. 76(301), pp. 176-196.

Booth, A.L. and Van Ours, J.C. (2013). 'Part-time jobs: what women want?', Journal of Population Economics, vol. 26(1), pp. 263-283.

Burda, M., Hamermesh, D.S. and Weil, P. (2013). 'Total work and gender: facts and possible explanations', Journal of Population Economics, vol. 26(1), pp. 239-261.

Clark, A.E. (2003). 'Unemployment as a social norm: Psychological evidence from panel data', Journal of Labor Economics, vol. 21(2), pp. 323-351.

Clark, A.E. and Oswald, A.J. (1998). 'Comparison-concave utility and following behaviour in social and economic settings', Journal of Public Economics, vol. 70(1), pp. 133-155.

Falk, A. and Ichino, A. (2006). 'Clean evidence on peer effects', Journal of Labor Economics, vol. 24(1), pp. 39-57.

Ferrer-i Carbonell, A. and Frijters, P. (2004). 'How important is methodology for the estimates of the determinants of happiness?', The Economic Journal, vol. 114(497), pp. 641-659.

Frijters, P. and Leigh, A. (2008). 'Materialism on the march: From conspicuous leisure to conspicuous consumption?', Journal of Socio-Economics, vol. 37(5), pp. 1937-1945.

Grodner, A. and Kniesner, T.J. (2006). 'Social interactions in labor supply', Journal of the European Economic Association, vol. 4(6), pp. 1226-1248.

Grodner, A. and Kniesner, T.J. (2008). 'Labor supply with social interactions: econometric estimates and their tax policy implications', Research in Labor Economics, vol. 28, pp. 1-23. 
Hamermesh, D.S. (2002). 'Timing, togetherness and time windfalls', Journal of Population Economics, vol. 15(4), pp. 601-623.

Hole, A.R., Dickerson, A. and Munford, L. (2011). 'A review of estimators for the fixed-effects ordered logit model', United Kingdom Stata Users' Group Meetings 2011.

Ichino, A. and Maggi, G. (2000). 'Work environment and individual background: explaining regional shirking differentials in a large italian firm', The Quarterly Journal of Economics, vol. 115(3), pp. 1057-1090.

Jenkins, S.P. and Osberg, L. (2004). 'Nobody to play with? the implications of leisure coordination', in (D. S. Hamermesh and G. A. Pfann, eds.), The Economics of Time Use (Contributions to Economic Analysis, Volume 271), pp. 113-145, Emerald Group Publishing Limited.

Kahneman, D. and Thaler, R.H. (2006). 'Anomalies: Utility maximization and experienced utility', The Journal of Economic Perspectives, vol. 20(1), pp. 221-234.

Lykken, D. and Tellegen, A. (1996). 'Happiness is a stochastic phenomenon', Psychological Science, vol. 7(3), pp. 186-189.

Manski, C.F. (1993). 'Identification of endogenous social effects: The reflection problem', The Review of Economic Studies, vol. 60(3), pp. 531-542.

Maurin, E. and Moschion, J. (2009). 'The social multiplier and labor market participation of mothers', American Economic Journal: Applied Economics, pp. 251-272.

Nickell, S. (1981). 'Biases in dynamic models with fixed effects', Econometrica: Journal of the Econometric Society, pp. 1417-1426.

Oswald, A.J. and Powdthavee, N. (2007). 'Obesity, unhappiness, and the challenge of affluence: theory and evidence', Economic Journal, vol. 117(6), pp. 441-454.

Rätzel, S. (2009). 'Revisiting the neoclassical theory of labour supply-disutility of labour, working hours, and happiness', Otto-von-Guericke University Magdeburg, Faculty of Economics and Management. 
Soetevent, A.R. (2006). 'Empirics of the identification of social interactions; an evaluation of the approaches and their results', Journal of Economic Surveys, vol. 20(2), pp. 193-228.

Stiglitz, J.E. (2008). 'Toward a general theory of consumerism: Reflections on keynes's economic possibilities for our grandchildren', L. Pecchi $\& 3$ G. Piga (red.), Revisiting Keynes: Economic possibilities for our grandchildren, pp. 41-86.

Stutzer, A. and Lalive, R. (2004). 'The role of social work norms in job searching and subjective well-being', Journal of the European Economic Association, vol. 2(4), pp. 696-719.

Topa, G. (2001). 'Social interactions, local spillovers and unemployment', The Review of Economic Studies, vol. 68(2), pp. 261-295.

Van der Klaauw, B. and Van Ours, J.C. (2003). 'From welfare to work: does the neighborhood matter?', Journal of Public Economics, vol. 87(5), pp. 957-985.

Van der Lippe, T. and Siegers, J.J. (1994). 'Division of household and paid labour between partners: effects of relative wage rates and social norms', Kyklos, vol. 47(1), pp. 109-136.

Veblen, T. (1899). The theory of the leisure class: An economic study in the evolution of institutions, Macmillan \& Company, Limited.

Vendrik, M. (1998). 'Unstable bandwagon and habit effects on labor supply', Journal of Economic Behavior \&3 Organization, vol. 36(2), pp. 235-255.

Vendrik, M. (2003). 'Dynamics of a household norm in female labour supply', Journal of Economic Dynamics and Control, vol. 27(5), pp. 823-841.

Weinberg, B.A., Reagan, P.B. and Yankow, J.J. (2004). 'Do neighborhoods affect hours worked? evidence from longitudinal data', Journal of Labor Economics, vol. 22(4), pp. 891-924.

Woittiez, I. and Kapteyn, A. (1998). 'Social interactions and habit formation in a model of female labour supply', Journal of Public Economics, vol. 70(2), pp. 185-205.

Wooldridge, J.M. (1995). 'Selection corrections for panel data models under conditional mean independence assumptions', Journal of Econometrics, vol. 68(1995), pp. 115-132. 


\section{Appendix A - Figures}

Figure A1: Histograms of the Variables of Interest
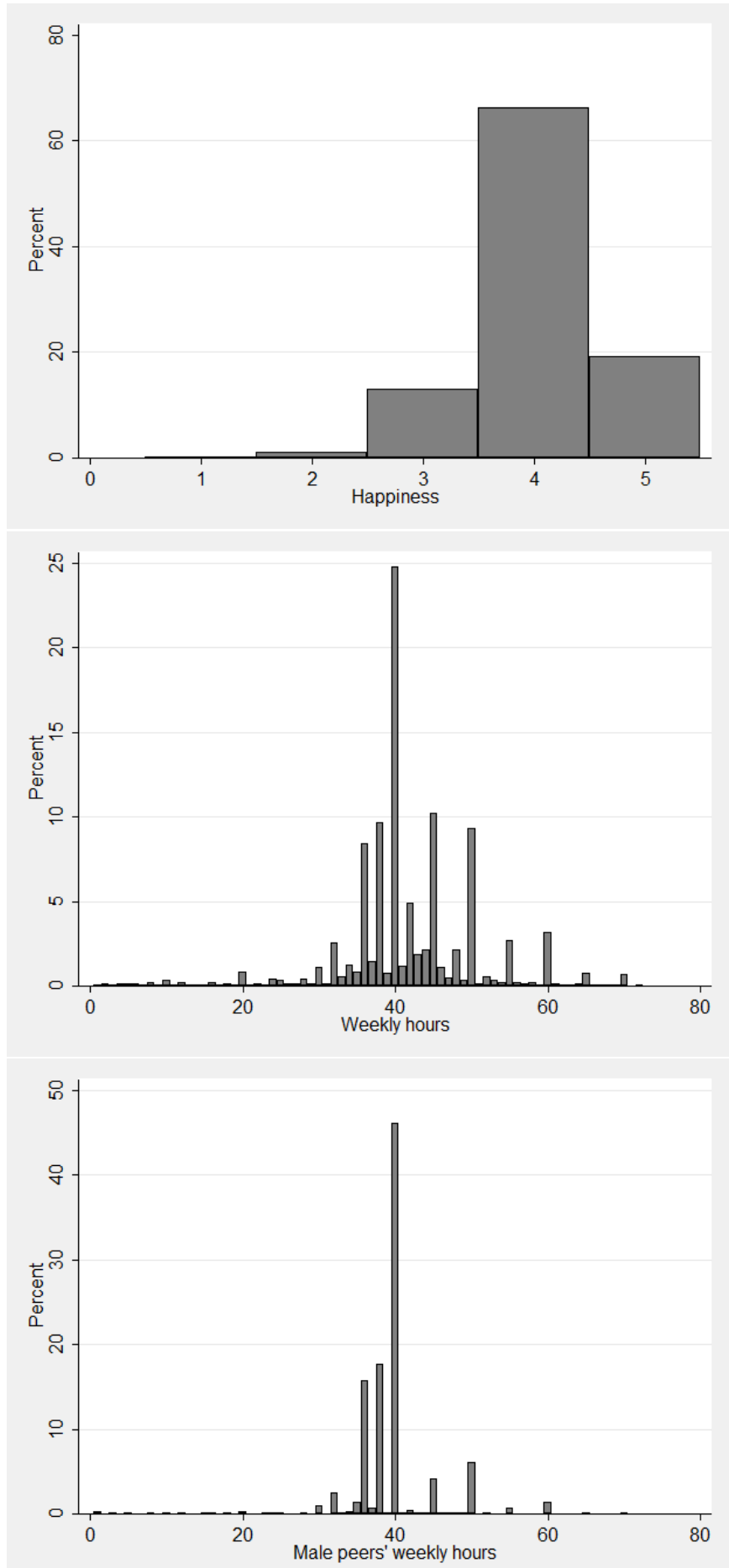
Figure A2: Scatterplot of Peer Hours against Own Hours

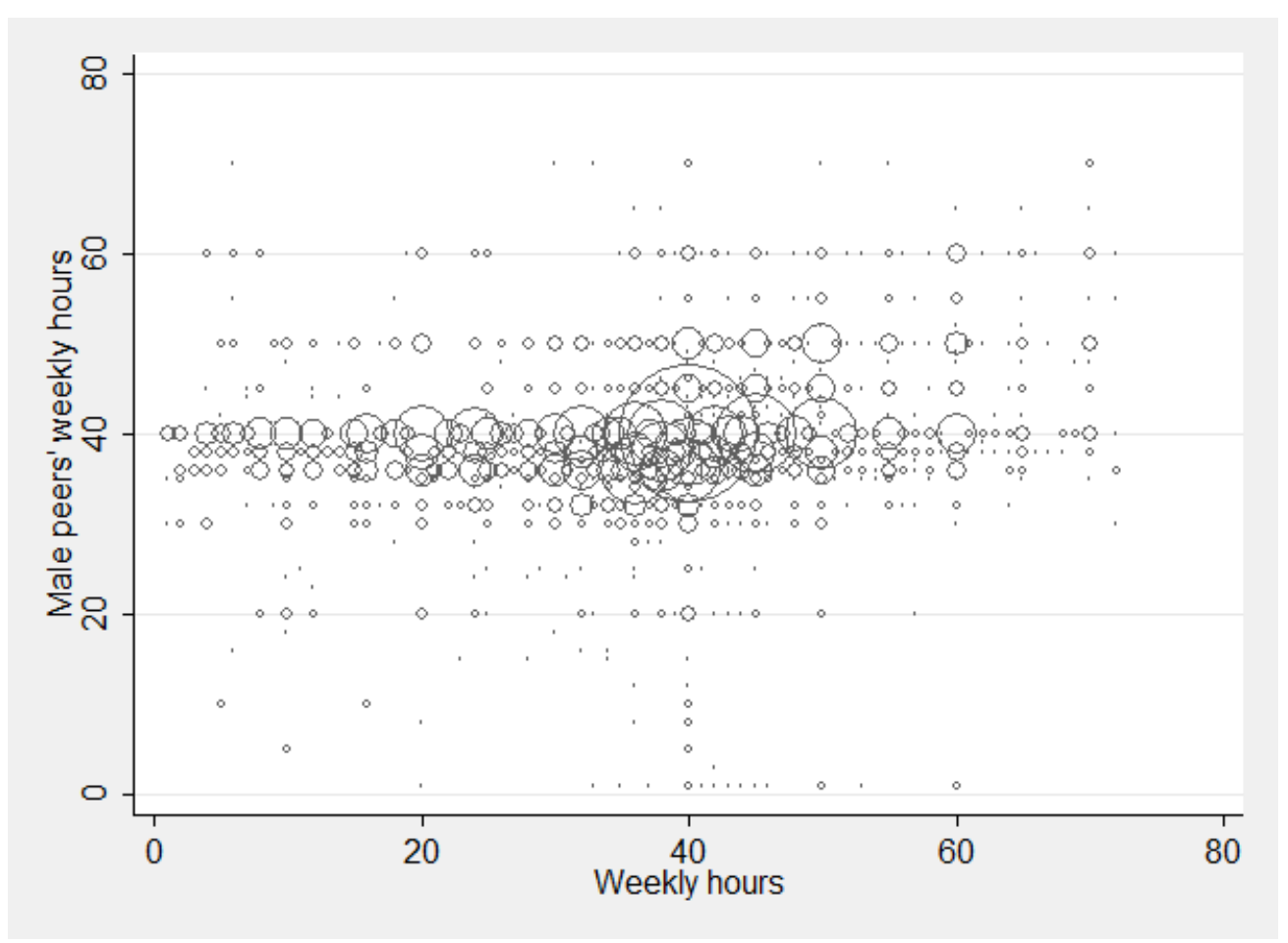




\section{Appendix B - Data}

\section{Data cleaning}

The data contained a number of implausibly high values for both own and peer weekly working time. We excluded observations with more than 72 weekly hours. This corresponds to dropping the top percentile of the distribution of own hours in our sample. We tried different upper limits for the hours variables, ranging from 60 hours to no limit. The choice of the upper limit had only very little influence on the main estimation results. The instances in which the thresholds influenced the results are mentioned in the results section (Section 4).

The CentER panel measures income in a very detailed way at the individual level, through a number of questions on sources of income, such as earnings, social benefits, and transfers from family. The total net household income is measured as the sum of the net incomes of the different members of a household. The data are organized to avoid double-counting in case different members of the same household mention the same income source. To eliminate implausibly low and implausibly high values of household income, we exclude the top and bottom $0.5 \%$ of the household income distribution. As for the hours, the choice of the threshold for cleaning the household income variable had very little impact on the estimation results.

\section{Prediction of missing values for peer income}

Table B1 presents the estimation results of the model used to predict peer income where it was missing. Admittedly, the coefficients estimated in this model can be influenced by selection bias if answering the peer income question is related to the level of peer income. To check for this possibility, we also estimated a simple linear model by ordinary least squares (OLS), with and without correction for selection (results available from the authors). As an instrument for selection, we used the lag of the number of missing answers to peer-related questions other than the question about peer income. (We could not use the present value since it was a perfect predictor of being part of the estimation sample.) There was very little variation in this variable, but it still had a negative and significant effect on the probability of answering the peer income question. We did find evidence that selection matters. However, in our equations of interest, whether we 
Table B1: Peer Income: Ordered Logit Model

\begin{tabular}{lc}
\hline Peer age & $0.5974^{* * *}$ \\
& $(0.0831)$ \\
Peer age ${ }^{-2}$ & $-0.0190^{* * *}$ \\
& $(0.0062)$ \\
Peer household size & $0.2109^{* * *}$ \\
& $(0.0227)$ \\
Most peers self-employed & -0.1205 \\
& $(0.0836)$ \\
Peer education level & $0.5754^{* * *}$ \\
& $(0.0166)$ \\
Male peers' weekly working time & $0.0347^{* * *}$ \\
& $(0.0039)$ \\
Female peers' weekly working time & 0.0012 \\
& $(0.0012)$ \\
\hline Observations & 7326 \\
\hline Standard errors in parentheses; $*$ p $<0.1 ; * *$ \\
$\mathrm{p}<0.05 ; * * * \mathrm{p}<0.01 ;$ Year dummies included as ad- \\
ditional controls.
\end{tabular}

used predicted peer income computed on the basis of the ordered logit, the simple OLS, or the Heckman model with the selection equation made very little difference to the estimation results. We therefore chose to use the linear prediction from the ordered logit because the distribution of the predicted peer income variable was most similar to that of the measured one. 


\section{Appendix C - Additional Tables}

Table C1: Correlations between Own and Peer characteristics

\begin{tabular}{|c|c|c|c|c|c|}
\hline Own / Peer Characteristics & Age & Household Size & Education Level & Weekly Hours & Self-employed \\
\hline Age & 0.8169 & & & & \\
\hline Household Size & & 0.5207 & & & \\
\hline Education Level & & & 0.6078 & & \\
\hline Weekly Hours & & & & 0.2832 & \\
\hline Self-employed & & & & & 0.2037 \\
\hline
\end{tabular}

Table C2: Cross-tables of Own and Peer Characteristics

Panel A - Cross-table of Age Groups

\begin{tabular}{lcccccc}
\hline Own / Peer Age & $<25$ & $25-34$ & $35-44$ & $45-54$ & $>=55$ & Total \\
\hline$<25$ & 53 & 8 & 1 & 0 & 0 & 62 \\
$25-34$ & 93 & 1,259 & 87 & 8 & 3 & 1,450 \\
$35-44$ & 24 & 699 & 1,817 & 65 & 6 & 2,611 \\
$45-54$ & 18 & 105 & 1,213 & 1,499 & 46 & 2,881 \\
$>=55$ & 9 & 19 & 136 & 763 & 272 & 1,199 \\
Total & 197 & 2,090 & 3,254 & 2,335 & 327 & 8,203 \\
\hline
\end{tabular}

Panel B - Cross-Table of Education Level

\begin{tabular}{lcccc}
\hline Own / Peer Level & Low & Middle & High & Total \\
\hline Low & 916 & 865 & 99 & 1,880 \\
Middle & 403 & 1,686 & 493 & 2,582 \\
High & 111 & 930 & 2,359 & 3,400 \\
Total & 1,430 & 3,481 & 2,951 & 7,862 \\
\hline
\end{tabular}


Table C3: Weekly Hours Worked: OLS Model with Fixed-Effects Including Lags and Peer Characteristics

\begin{tabular}{|c|c|c|c|}
\hline & (1) & $(2)$ & $(3)$ \\
\hline Male peers' weekly hours & $\begin{array}{c}0.1095^{* * *} \\
(0.0391)\end{array}$ & & $\begin{array}{c}0.0857^{* * *} \\
(0.0289)\end{array}$ \\
\hline Lag of own weekly hours & $\begin{array}{c}0.0882^{* * *} \\
(0.0290)\end{array}$ & & \\
\hline Lag of peer hours & & $\begin{array}{c}0.0611^{* *} \\
(0.0276)\end{array}$ & \\
\hline Peer age & & & $\begin{array}{l}-0.0285 \\
(0.0825)\end{array}$ \\
\hline Peer household size & & & $\begin{array}{l}-0.0499 \\
(0.1210)\end{array}$ \\
\hline Peer education level & & & $\begin{array}{c}0.1571 \\
(0.1928)\end{array}$ \\
\hline Most peers self-employed & & & $\begin{array}{c}1.0979 * * * \\
(0.3725)\end{array}$ \\
\hline Log net peer household income & $\begin{array}{c}1.4528^{* *} \\
(0.7255)\end{array}$ & $\begin{array}{c}1.8320^{* *} \\
(0.7632)\end{array}$ & $\begin{array}{c}0.6901 \\
(0.6109)\end{array}$ \\
\hline Age & $\begin{array}{c}0.9785^{* * *} \\
(0.2973)\end{array}$ & $\begin{array}{c}1.0839 * * * \\
(0.3676)\end{array}$ & $\begin{array}{c}0.8594^{* * *} \\
(0.2720)\end{array}$ \\
\hline Age $\widehat{2}$ & $\begin{array}{c}-0.0122^{* * *} \\
(0.0031)\end{array}$ & $\begin{array}{c}-0.0137^{* * *} \\
(0.0038)\end{array}$ & $\begin{array}{c}-0.0110^{* * *} \\
(0.0029)\end{array}$ \\
\hline Number of children & $\begin{array}{l}-0.3568 \\
(0.2770)\end{array}$ & $\begin{array}{l}-0.4338 \\
(0.3202)\end{array}$ & $\begin{array}{l}-0.0807 \\
(0.2597)\end{array}$ \\
\hline Partner & $\begin{array}{l}-0.0483 \\
(0.7482)\end{array}$ & $\begin{array}{l}-0.5024 \\
(0.6006)\end{array}$ & $\begin{array}{c}0.4209 \\
(0.7810)\end{array}$ \\
\hline Constant & $\begin{array}{l}12.6744^{*} \\
(7.5035)\end{array}$ & $\begin{array}{c}16.3611^{*} \\
(9.1062)\end{array}$ & $\begin{array}{c}20.7639 * * * \\
(6.3027)\end{array}$ \\
\hline Observations & 5,692 & 5,005 & 8,203 \\
\hline Individuals & 2,082 & 1,840 & 3,042 \\
\hline$R^{2}$ & 0.05 & 0.04 & 0.03 \\
\hline
\end{tabular}


Table C4: Weekly Hours Worked: Pooled OLS Model

\begin{tabular}{lc}
\hline & $(1)$ \\
\hline Male peers' weekly hours & $0.4158^{* * *}$ \\
& $(0.0184)$ \\
Log net peer household income & $1.4661^{* * *}$ \\
& $(0.4625)$ \\
Age & $0.6462^{* * *}$ \\
& $(0.1049)$ \\
Age 2 & $-0.0083^{* * *}$ \\
& $(0.0012)$ \\
Number of children & 0.0820 \\
& $(0.0931)$ \\
Partner & $0.4964^{*}$ \\
& $(0.2833)$ \\
Constant & $9.8510^{* * *}$ \\
& $(2.3787)$ \\
\hline Observations & 8203 \\
$R^{2}$ & 0.11 \\
\hline Standard errors in parentheses; ${ }^{*} \mathrm{p}<0.1 ;{ }^{* *}$ \\
$\mathrm{p}<0.05 ;{ }^{* * *} \mathrm{p}<0.01 ;$ Year dummies included as \\
additional controls.
\end{tabular}


Table C5: Desired Working Time: OLS Model with Fixed-Effects

\begin{tabular}{lc}
\hline Male peers' weekly hours & $0.0677^{*}$ \\
& $(0.0363)$ \\
Log net peer household income & 0.3271 \\
& $(0.8677)$ \\
Age & $0.7113^{* *}$ \\
& $(0.3307)$ \\
Age 2 & $-0.0109^{* * *}$ \\
& $(0.0036)$ \\
Number of children & -0.7424 \\
& $(0.4942)$ \\
Partner & 0.5076 \\
& $(0.9786)$ \\
Constant & $23.2999^{* * *}$ \\
& $(7.4174)$ \\
\hline Observations & 8203 \\
Individuals & 3042 \\
$R^{2}$ & 0.02 \\
\hline Standard errors (clustered by individual) in \\
parentheses; ${ }^{*} \mathrm{p}<0.1 ;{ }^{*} \mathrm{p}<0.05 ; * * * 0.01 ;$ \\
Year dummies included as additional controls.
\end{tabular}


Table C6: Happiness: Ordered Logit Models with Fixed-Effects

\begin{tabular}{|c|c|c|c|c|}
\hline & $\begin{array}{c}(1) \\
\text { BUC }\end{array}$ & $\begin{array}{c}(2) \\
\text { BUC }\end{array}$ & $\begin{array}{c}(3) \\
\mathrm{FCF}\end{array}$ & $\begin{array}{c}(4) \\
\text { FCF }\end{array}$ \\
\hline Weekly working time & $\begin{array}{c}0.0583^{* *} \\
(0.0269)\end{array}$ & $\begin{array}{c}0.0628^{* *} \\
(0.0286)\end{array}$ & $\begin{array}{l}0.0519^{*} \\
(0.0290)\end{array}$ & $\begin{array}{l}0.0506^{*} \\
(0.0291)\end{array}$ \\
\hline Weekly working time $\widehat{2}$ & $\begin{array}{l}-0.0006^{*} \\
(0.0003)\end{array}$ & $\begin{array}{l}-0.0006^{*} \\
(0.0004)\end{array}$ & $\begin{array}{l}-0.0005 \\
(0.0004)\end{array}$ & $\begin{array}{l}-0.0005 \\
(0.0004)\end{array}$ \\
\hline Male peers' weekly working time & & $\begin{array}{c}-0.0228^{* *} \\
(0.0100)\end{array}$ & & $\begin{array}{c}-0.0255^{* * *} \\
(0.0096)\end{array}$ \\
\hline Log net peer household income & & $\begin{array}{l}-0.1858 \\
(0.2302)\end{array}$ & & $\begin{array}{l}-0.2938 \\
(0.2272)\end{array}$ \\
\hline Log net household income & $\begin{array}{c}0.1558^{*} \\
(0.0865)\end{array}$ & $\begin{array}{c}0.1725^{* *} \\
(0.0863)\end{array}$ & $\begin{array}{c}0.1402 \\
(0.0870)\end{array}$ & $\begin{array}{l}0.1501^{*} \\
(0.0875)\end{array}$ \\
\hline Looking for another job & $\begin{array}{c}-0.3604^{* * *} \\
(0.1211)\end{array}$ & $\begin{array}{c}-0.3598^{* * *} \\
(0.1214)\end{array}$ & $\begin{array}{c}-0.3809^{* * *} \\
(0.1135)\end{array}$ & $\begin{array}{c}-0.3980 * * * \\
(0.1140)\end{array}$ \\
\hline Subjective health & $\begin{array}{c}0.4760^{* * *} \\
(0.0924)\end{array}$ & $\begin{array}{c}0.4853^{* * *} \\
(0.0926)\end{array}$ & $\begin{array}{c}0.4937 * * * \\
(0.0933)\end{array}$ & $\begin{array}{c}0.5073^{* * *} \\
(0.0937)\end{array}$ \\
\hline Age & $\begin{array}{c}-0.2281^{*} \\
(0.1180)\end{array}$ & $\begin{array}{l}-0.2214^{*} \\
(0.1185)\end{array}$ & $\begin{array}{c}-0.2320^{* *} \\
(0.0933)\end{array}$ & $\begin{array}{c}-0.2145^{* *} \\
(0.0939)\end{array}$ \\
\hline Age $\widehat{2}$ & $\begin{array}{c}0.0029 * * \\
(0.0013)\end{array}$ & $\begin{array}{c}0.0028^{* *} \\
(0.0013)\end{array}$ & $\begin{array}{c}0.0030 * * * \\
(0.0010)\end{array}$ & $\begin{array}{c}0.0028^{* * *} \\
(0.0010)\end{array}$ \\
\hline Number of children & $\begin{array}{l}-0.0210 \\
(0.1323)\end{array}$ & $\begin{array}{l}-0.0313 \\
(0.1324)\end{array}$ & $\begin{array}{c}0.0024 \\
(0.1086)\end{array}$ & $\begin{array}{c}0.0070 \\
(0.1091)\end{array}$ \\
\hline Partner & $\begin{array}{c}1.5152^{* * *} \\
(0.4133)\end{array}$ & $\begin{array}{c}1.5237^{* * *} \\
(0.4122)\end{array}$ & $\begin{array}{c}1.5210^{* * *} \\
(0.2947)\end{array}$ & $\begin{array}{c}1.5353^{* * *} \\
(0.2952)\end{array}$ \\
\hline Observations & 4252 & 4252 & 3722 & 3722 \\
\hline Individuals & 777 & 777 & 777 & 777 \\
\hline
\end{tabular}

Standard errors in parentheses; ${ }^{*} \mathrm{p}<0.1$; $^{* *} \mathrm{p}<0.05$; ${ }^{* * *} \mathrm{p}<0.01$; Year dummies included as additional controls. 
Table C7: Happiness: OLS Model with Fixed-Effects Including Hours Difference in a Non-Linear Way

\begin{tabular}{|c|c|c|c|c|}
\hline & (1) & $(2)$ & (3) & (4) \\
\hline Weekly hours & $\begin{array}{l}0.0151^{* *} \\
(0.0076)\end{array}$ & $\begin{array}{c}0.0023 \\
(0.0066)\end{array}$ & $\begin{array}{c}0.0071 \\
(0.0044)\end{array}$ & $\begin{array}{c}0.0046 \\
(0.0038)\end{array}$ \\
\hline Weekly hours`2 & $\begin{array}{c}-0.0002^{* *} \\
(0.0001)\end{array}$ & $\begin{array}{l}-0.0000 \\
(0.0001)\end{array}$ & $\begin{array}{l}-0.0001 \\
(0.0001)\end{array}$ & $\begin{array}{l}-0.0001 \\
(0.0000)\end{array}$ \\
\hline Difference in hours & $\begin{array}{c}0.0034 \\
(0.0021)\end{array}$ & $\begin{array}{c}0.0023 \\
(0.0018)\end{array}$ & & \\
\hline Difference in hours $\widehat{2}$ & $\begin{array}{c}0.0001^{* *} \\
(0.0001)\end{array}$ & $\begin{array}{l}-0.0000 \\
(0.0001)\end{array}$ & & \\
\hline Working less hours than peers & & & $\begin{array}{c}-0.0492^{* *} \\
(0.0239)\end{array}$ & $\begin{array}{c}-0.0575^{* *} \\
(0.0234)\end{array}$ \\
\hline Working more hours than peers & & & $\begin{array}{l}-0.0048 \\
(0.0187)\end{array}$ & $\begin{array}{l}-0.0037 \\
(0.0188)\end{array}$ \\
\hline Log net household income & $\begin{array}{l}0.0255^{*} \\
(0.0148)\end{array}$ & $\begin{array}{c}0.0233 \\
(0.0143)\end{array}$ & $\begin{array}{l}0.0269^{*} \\
(0.0147)\end{array}$ & $\begin{array}{l}0.0237^{*} \\
(0.0144)\end{array}$ \\
\hline Log net peer household income & $\begin{array}{l}-0.0184 \\
(0.0455)\end{array}$ & $\begin{array}{c}0.0488 \\
(0.0472)\end{array}$ & $\begin{array}{l}-0.0641 \\
(0.0442)\end{array}$ & $\begin{array}{c}0.0510 \\
(0.0473)\end{array}$ \\
\hline Looking for another job & $\begin{array}{c}-0.0530^{* * *} \\
(0.0197)\end{array}$ & $\begin{array}{c}-0.0535^{* * *} \\
(0.0199)\end{array}$ & $\begin{array}{c}-0.0519^{* * *} \\
(0.0197)\end{array}$ & $\begin{array}{c}-0.0526^{* * *} \\
(0.0198)\end{array}$ \\
\hline Subjective health & $\begin{array}{c}0.0823^{* * *} \\
(0.0154)\end{array}$ & $\begin{array}{c}0.0832^{* * *} \\
(0.0154)\end{array}$ & $\begin{array}{c}0.0823^{* * *} \\
(0.0154)\end{array}$ & $\begin{array}{c}0.0833^{* * *} \\
(0.0154)\end{array}$ \\
\hline Age & $\begin{array}{c}-0.0343^{*} \\
(0.0204)\end{array}$ & $\begin{array}{c}-0.0362^{*} \\
(0.0205)\end{array}$ & $\begin{array}{l}-0.0329 \\
(0.0204)\end{array}$ & $\begin{array}{c}-0.0364^{*} \\
(0.0205)\end{array}$ \\
\hline Age 2 & $\begin{array}{l}0.0004^{*} \\
(0.0002)\end{array}$ & $\begin{array}{l}0.0004^{*} \\
(0.0002)\end{array}$ & $\begin{array}{l}0.0004^{*} \\
(0.0002)\end{array}$ & $\begin{array}{l}0.0004^{*} \\
(0.0002)\end{array}$ \\
\hline Number of children & $\begin{array}{l}-0.0031 \\
(0.0206)\end{array}$ & $\begin{array}{c}0.0023 \\
(0.0207)\end{array}$ & $\begin{array}{l}-0.0032 \\
(0.0207)\end{array}$ & $\begin{array}{c}0.0031 \\
(0.0208)\end{array}$ \\
\hline Partner & $\begin{array}{c}0.3191^{* * *} \\
(0.0864)\end{array}$ & $\begin{array}{c}0.3104^{* * *} \\
(0.0865)\end{array}$ & $\begin{array}{c}0.3214^{* * *} \\
(0.0862)\end{array}$ & $\begin{array}{c}0.3127^{* * *} \\
(0.0864)\end{array}$ \\
\hline Constant & $\begin{array}{c}3.6247^{* * *} \\
(0.5317)\end{array}$ & $\begin{array}{c}3.7974^{* * *} \\
(0.5071)\end{array}$ & $\begin{array}{c}3.7623^{* * *} \\
(0.5015)\end{array}$ & $\begin{array}{c}3.7339^{* * *} \\
(0.4899)\end{array}$ \\
\hline Observations & 8,203 & 8,149 & 8,203 & 8,149 \\
\hline Individuals & 3,042 & 3,026 & 3,042 & 3,026 \\
\hline$R^{2}$ & 0.04 & 0.04 & 0.04 & 0.04 \\
\hline
\end{tabular}

Standard errors (clustered by individual) in parentheses; ${ }^{*} \mathrm{p}<0.1 ;{ }^{* *} \mathrm{p}<0.05$; *** $\mathrm{p}<0.01$; Year dummies included as additional controls. 
Table C8: Happiness: OLS Model with Fixed-Effects, Controlling for Exogenous Effects

\begin{tabular}{lc}
\hline Weekly hours & $0.0095^{* *}$ \\
& $(0.0042)$ \\
Weekly hours 2 & $-0.0001^{*}$ \\
& $(0.0000)$ \\
Male peers' weekly hours & $-0.0041^{* *}$ \\
& $(0.0020)$ \\
Peer age & -0.0021 \\
& $(0.0091)$ \\
Peer household size & -0.0028 \\
& $(0.0099)$ \\
Peer education level & 0.0256 \\
& $(0.0158)$ \\
Most peers self-employed & -0.0090 \\
& $(0.0344)$ \\
Log net household income & $0.0269^{*}$ \\
& $(0.0147)$ \\
Log net peer household income & -0.0508 \\
& $(0.0446)$ \\
Looking for another job & $-0.0530^{* * *}$ \\
& $(0.0197)$ \\
Subjective health & $0.0818^{* * *}$ \\
& $(0.0154)$ \\
Age & -0.0318 \\
& $(0.0205)$ \\
Age`2 & $0.0004^{*}$ \\
& $(0.0002)$ \\
Number of children & -0.0028 \\
& $(0.0206)$ \\
Partner & $0.3192^{* * *}$ \\
Constant & $(0.0862)$ \\
& $3.7742^{* * *}$ \\
\hline Observations & $(0.5123)$ \\
\hline$R^{2}$ & 8,203 \\
\hline & 3,042 \\
Standuals & 0.04 \\
\hline
\end{tabular}

Standard errors (clustered by individual) in parentheses; * $\mathrm{p}<0.1 ;{ }^{* *} \mathrm{p}<0.05 ; * * * \mathrm{p}<0.01$;

Year dummies included as additional controls. 
Table C9: Happiness: Pooled OLS Models

\begin{tabular}{lcc}
\hline & $(1)$ & $(2)$ \\
\hline Weekly hours & $0.0060^{* *}$ & $0.0061^{* *}$ \\
Weekly hours`2 & $(0.0028)$ & $(0.0028)$ \\
& -0.0000 & -0.0000 \\
Male peers' weekly hours & $(0.0000)$ & $(0.0000)$ \\
& & 0.0006 \\
Log net household income & $0.0309^{* * *}$ & $(0.0013)$ \\
& $(0.0110)$ & $(0.0113)$ \\
Log net peer household income & & -0.0192 \\
& & $(0.0316)$ \\
Looking for another job & $-0.0860^{* * *}$ & $-0.0859^{* * *}$ \\
& $(0.0164)$ & $(0.0164)$ \\
Subjective health & $0.2721^{* * *}$ & $0.2722^{* * *}$ \\
& $(0.0102)$ & $(0.0102)$ \\
Age & -0.0111 & -0.0106 \\
& $(0.0070)$ & $(0.0071)$ \\
Age`2 & 0.0001 & 0.0001 \\
& $(0.0001)$ & $(0.0001)$ \\
Number of children & $-0.0231^{* * *}$ & $-0.0232^{* * *}$ \\
& $(0.0062)$ & $(0.0062)$ \\
Partner & $0.4162^{* * *}$ & $0.4173^{* * *}$ \\
Constant & $(0.0189)$ & $(0.0190)$ \\
& $2.4249^{* * *}$ & $2.4120^{* * *}$ \\
\hline Observations & $(0.1851)$ & $(0.1901)$ \\
$R^{2}$ & 8203 & 8203 \\
\hline Standard errors in parentheses; $* \mathrm{p}<0.1 ; * *$ & $\mathrm{p}<0.05 ; * * *$ \\
$\mathrm{p}<0.01 ;$ Year dummies included as additional & controls.
\end{tabular}

